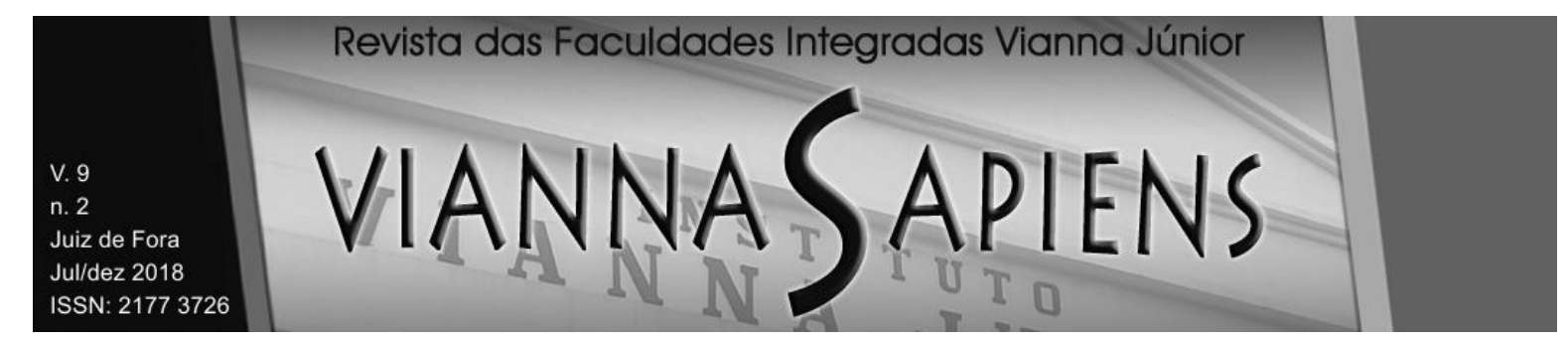

\title{
AUTONOMIA E CIDADANIA SOBERANAS PARA VENCER A COLONIALIDADE E A CORRUPÇÃO
}

DOI: 10.31994/rvs.v9i2.449

\author{
Rafael Sales Pimenta ${ }^{1}$ \\ Gabriela de Souza Pimenta²
}

\section{RESUMO}

A colonização é um véu que cobre as colônias por décadas ou séculos. O sentimento de ser colônia e ver-se bem nesta situação, de colono, pode permanecer ou ser expurgado das consciências dos colonos após a independência. Noutros casos, o sentimento permanece após décadas ou séculos, que tratam seus destinos sob uma colonialidade que não conseguem perceber ou refutar. Buscar os caminhos para romper a colonialidadeé o objetivo deste artigo e o faremos por meio da pesquisa bibliográfica e documental. A decolonialidade é como uma profanação do sagrado altar de violência, massacre, usurpação, preconceitos variados, exploração secular, corrupção, tudo em nome da democracia, direitos individuais e direitos humanos, que são a todo tempo ditos que alcançamos com processos eleitorais. $\mathrm{Na}$ conclusão, perceberemos nossa colonialidade a confrontar, buscando assegurar a diversidade constitucional para todos os segmentos sociais minoritários, tais como negros, mulheres, pobres, povos originários ou quilombolas é o caminho para rompermos séculos de inferioridade. O povo só deixará a condição de colônia, depois da independência formal, mediante autorreconhecimento e luta pela independência efetiva.

\footnotetext{
${ }^{1}$ Graduado em Direito UFMG, Pós-graduado em Direito Processual Civil CAD/UGF, Mestre em Hermenêutica e Direitos Fundamentais UNIPAC JF, Doutor em Direito Internacional dos Direitos Humanos PUC Minas. Professor e advogado. ORCID: <https://orcid.org/0000-0002-9855-9536>

${ }^{2}$ Graduada em Direito FVJ JF. Advogada. ORCID: <https://orcid.org/0000-0002-1410-3583>
} 


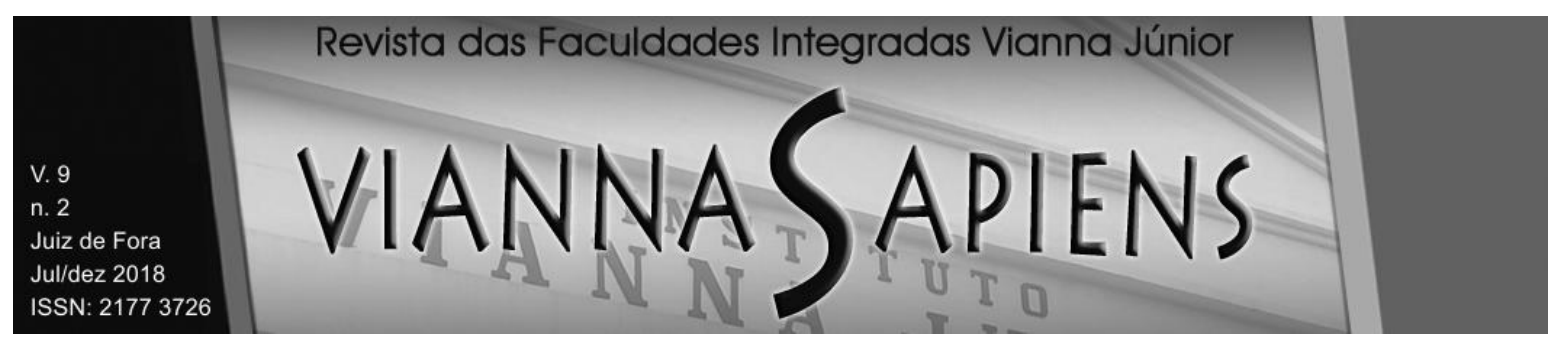

PALAVRAS-CHAVE: COLÔNIA. COLONIALIDADE. CORRUPÇÃ. CIDADANIA.

\title{
SOVEREIGN AUTONOMY AND CITIZENSHIP TO WIN COLONIALITY AND CORRUPTION
}

\begin{abstract}
Colonization is a veil that covers the colonies for decades or centuries. The feeling of being a colony and seeing oneself well in this colonist situation can remain or be purged of the colonists consciousness after independence. In other cases, the feeling of being a colony remains after decades or centuries, which treat their destinations under a coloniality that they can not perceive or refute. The search for breaking this chain is what we will focus on through bibliographic and documentary research. The decoloniality is like a desecration of the sacred altar of violence, massacre, usurpation, varied prejudices, secular exploration, corruption, all in the name of democracy, individual rights and human rights, which are at all times said that we achieve with electoral processes. We realize our coloniality, when confronted, seeking to ensure constitutional diversity for all minority social segments, such as black people, women, poor people, native people and quilombolas is the way to break through centuries or inferiority. People only leaves its condition of colony after the formal independence, by self-recognition and fight for the effective independence.
\end{abstract}

KEY WORDS: COLONY. COLONIALITY. CORRUPTION. CITIZENSHIP. 


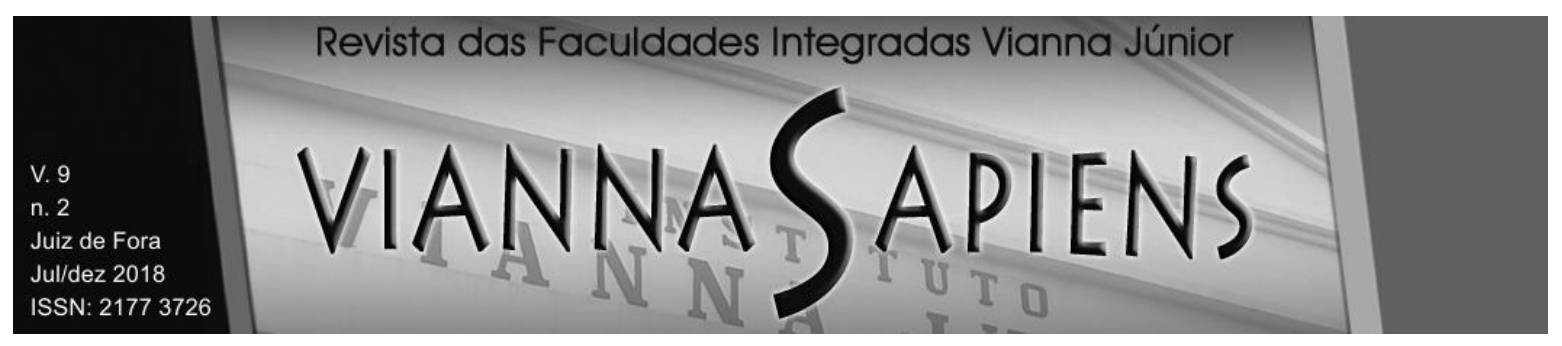

\section{INTRODUÇÃO}

A colonização é um véu que cobre as colônias por décadas ou séculos. $O$ sentimento de ser colônia e ver-se bem nesta situação, de colono, pode permanecer ou ser banido das consciências dos povos após a independência. Noutros casos, o sentimento de ser colônia permanece após séculos, sob uma colonialidade que não conseguem perceber ou refutar. O sentimento de colonialidade é sagrado para todos os que se acomodam bem na situação inferior do explorado-explorador. A decolonialidade é como uma profanação do sagrado altar de violência, massacre, usurpação, preconceitos variados, exploração secular, corrupção, tudo em nome da democracia, direitos individuais e direitos humanos, que são a todo tempo dito que alcançamos com processos eleitorais. Ao contrário disso, um povo só deixa esta condição de colônia, depois da independência formal, mediante autorreconhecimento e luta pela independência efetiva.

Mas esta é uma tarefa de difícil percepção, pois a sociedade é laboriosa e meticulosamente alienada, incentivam-se os preconceitos raciais, de inferioridade e de todo tipo, corrompem-se os governantes para que se acomodem na simpatia do explorador, que usurpa todas as riquezas por 500 anos e seguem assim. Felizes ambos, com sua justificação de que o Estado mínimo é o melhor e a economia deve ser gerida pelo capital financeiro internacional. Direitos sociais podem ser disponibilizados à população, mas somente após o cumprimento da lei de responsabilidade fiscal. Primeiro pagam-se os bancos, depois cuida-se da população e carreiam-se as riquezas minerais, entre elas o petróleo, para os países do norte.

Vamos desenvolver a discussão a partir da verificação de que agimos como colônia desde 1500, demonstrando o período da exploração mineral aberta e sem subterfúgios. No segundo tópico afirmaremos que a dignidade do povo e de cada cidadão é que deve ser enfocada na busca por uma mudança de cenário nacional. $O$ terceiro título afirma a necessidade de deixar este caminho e buscar outro rumo na busca pela soberania nacional e cidadania de seu povo. No quarto item a busca da 


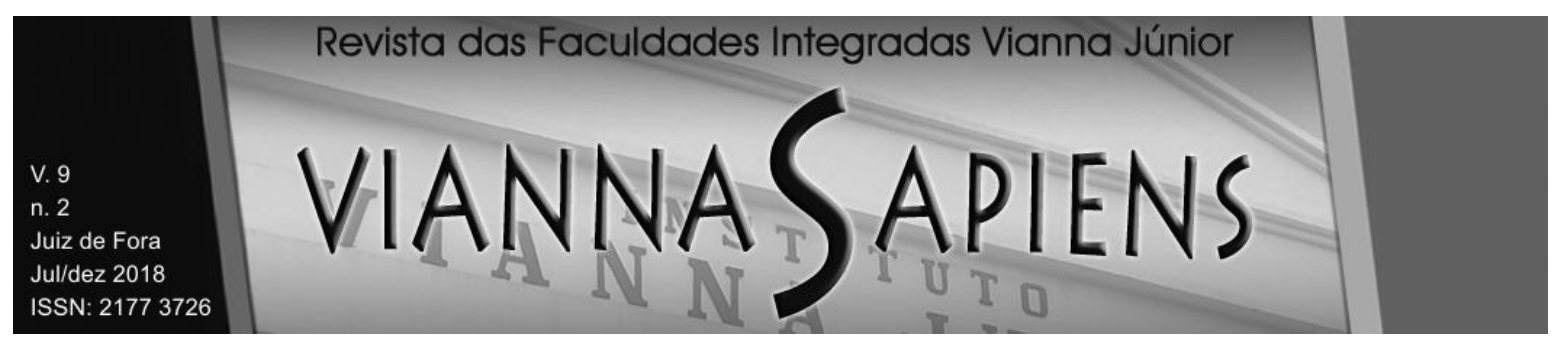

identidade mais integral possível como encontro da vontade nacional soberana com a identificação de todos os segmentos sociais com sua própria origem e sua compreensão de ser dono de seu destino é o centro da argumentação.Em conclusão, é preciso que boa parte dos cidadãos se reconheça em condições iguais de trabalho e subsistência, atuando firmemente na luta e conscientização de todos pela igualdade racial, de gênero e de classe para empoderar a população como um todo. Mas é certo que este será um processo em que a população deve tomar em suas mãos essas novas perspectivas. Romper com a alienação e o sentimento de inferioridade e de ser colônia é processo que deve ser alcançado.

Nosso objetivo é situarmos o atual estado de coisas na vida das colônias, chamando atenção para o resgate da dignidade desses povos, a necessidade da busca por um outro caminho a ser seguido e a possibilidade da busca pela identidade integral dos segmentos sociais do país no encontro da autonomia e da cidadania, tudo por meio da pesquisa bibliográfica e documental.

\section{UM ESTADO DE COISAS SECULAR - OURO E PRATA ENLOUQUECEM OS CAPITALISTAS, O DINHEIRO OS FASCINA}

A colonização é um véu que cobre as colônias por décadas ou séculos. $O$ sentimento de ser colônia e ver-se bem nesta situação de colono pode permanecer ou ser expurgado das consciências dos povos após a independência. Noutros casos, o sentimento de ser colônia permanece após séculos e trata seus destinos sob uma colonialidade que não conseguem perceber ou refutar. O sentimento de colonialidade é sagrado para todos os que se acomodam bem na situação inferior do explorado-explorador. A decolonialidade é como uma profanação do sagrado altar de violência, massacre, usurpação, preconceitos variados, exploração secular, corrupção, tudo em nome da democracia, direitos individuais e direitos humanos, que são a todo tempo dito que alcançamos com processos eleitorais (AGAMBEM, 2007, p. 57). 


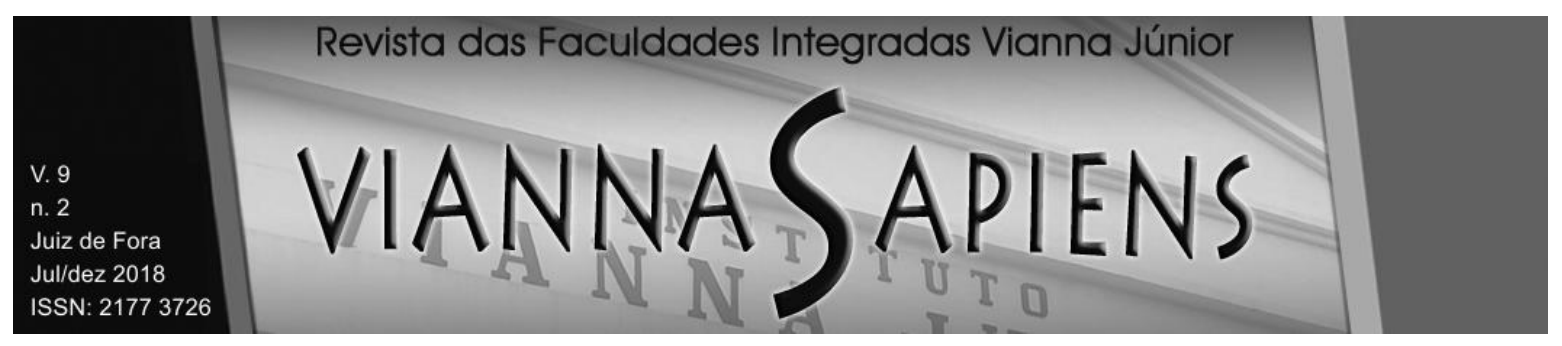

As sociedades estão em transformação e a complexidade do mundo está exigindo novas formas de manifestação do fenômeno jurídico. É possível que, não tão distantemente no futuro, essa forma compacta do direito instrumentalizado, uniformizado e generalizado sob a forma estatal de organização venha a implodir, recuperando-se, em manifestações espontâneas e localizadas, um direito de muitas faces, peculiar aos grupos e às pessoas que os compõem (FERRAZ JUNIOR, 2003, p. 23).

Basta, para afirmá-lo, observar o processo eleitoral brasileiro em que as redes sociais tiveram uma interferência maior que as mídias convencionais na definição da opinião pública.Virar a página de 500 anos de servidão colonial não é tarefa fácil. Foram 322 anos como colônia formal, mais 67 anos de colonialismo indireto e de colonialidade integral até a república. Na república, foram 127 anos de colonialidade até os dias atuais do mesmo colonialismo indireto, agora não a Portugal, mas aos países do norte (hemisférico e no sentido figurativo), sejam eles nomeados conforme o tema em questão.

Para Santos (2007, p. 3) , as linhas cartográficas que demarcavam o Velho e o Novo Mundo na era colonial, permanecem estruturalmente no pensamento moderno ocidental do século XXI e são constitutivas das relações políticas e culturais excludentes mantidas no sistema mundial contemporâneo.

Um dos mais grotescos exemplos da usurpação do norte sobre o sul está dentro dos museus europeus, onde se espalham peças de característico valor cultural dos povos explorados que deveriam estar expostos nos museus de cada canto do mundo, num reconhecimento da diversidade cultural do mundo, mas que o europeu guarda para si e o protege contra a incúria dos povos atrasados.

Mas, ao contrário de uma concepção harmoniosa e ambientalmente sustentável, o sistema-mundo capitalista forjou-se como sistema essencialmente econômico que determina as posturas dos atores sociais e políticos para uma lógica econômica da obtenção de lucro, produção de excedentes e na incessante acumulação de capital em escala mundial (GROSFOGUEL, 2010, p. 462). Todavia não é somente econômico este modelo. Ele é mais que isso, ele é um conjunto de relações de poder, apoiado na matriz de poder colonial do capitalismo. O capitalismo 


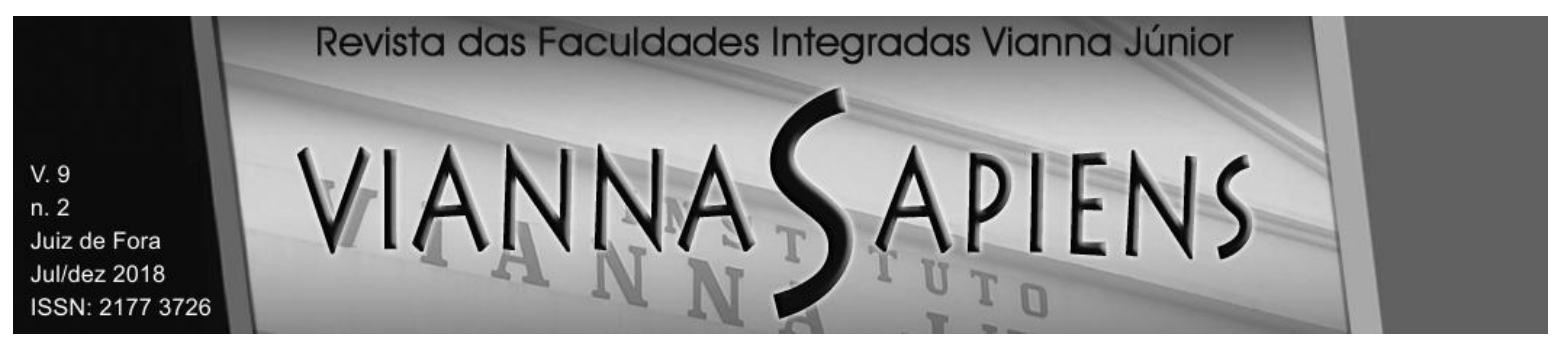

econômico mundial se apóia, desde a modernidade do século $\mathrm{XV}$, na superioridade do europeu e na inferioridade do ameríndio, hoje da América do Sul, Central e África.

Para Grosfoguel ( 2010) não há como se pensar como iguais ou sinônimas a descolonização e a libertação anticapitalista. Deixar de ser colônia no sentido literal, diversos países deixaram, o Brasil entre eles, mas permanecem circunscritos na tutela capitalista dos países do norte. Para se obter a libertação colonial e anticapitalista, é preciso evoluir a uma nova concepção de sociedade que atue na transformação das hierarquias de gênero, espirituais, epistêmicas, econômicas, políticas, linguísticas e raciais, de uma forma não redutora.

\section{O RESGATE DA DIGNIDADE}

Conceitualmente, situa-se a dignidade da pessoa humana como chave mestra de sustentação e legitimação da República, inserida entre os princípios constitucionais. Ela ergue-se como linha decisiva de fronteira contra totalitarismos (políticos, sociais, religiosos ou econômicos), contra posturas redutoras de um povo a uma condição inferior à que devia ocupar e contra experiências históricas de aniquilação existencial do ser humano e negadoras dessa mesma dignidade da pessoa humana.

A dignidade, inclusive coletivamente considerada, é vista como um princípio de proteção universal em favor de um povo e em contrário à desvirtuação dessa mesma dignidade, que obriga à adoção de convenções e medidas internacionais contra a sua violação e à formação de um direito internacional adequado à proteção da dignidade da pessoa humana (CANOTILHO, 1998). Mas, não apenas como ser humano individual e concretamente considerado, mas também da dignidade humana referente a entidades coletivas (humanidade, povos, etnias). 


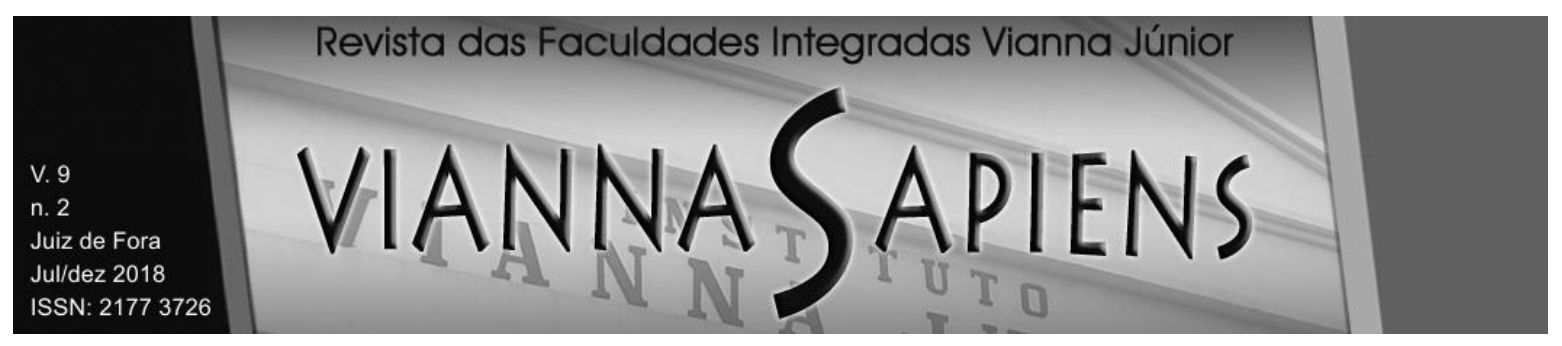

Buscar a defesa de seu patrimônio cultural e natural é direito e é dever da sociedade. Atuar em direção à autonomia e liberdade de escolha de seu modelo e padrão de desenvolvimento é o que se espera de um povo e um país livre.

A colonialidade do poder em relação aos países do norte se demonstra também na percepção de que não é somente econômica a dependência, ela é fundamentalmente cultural e ideológica (GROSFOGUEL, 2010).

Existem diversos movimentos revolucionários autênticos no mundo atual. Todos lutam contra o "velho Estado" como uma definição do que seja o Estado arcaico do subdesenvolvimento capitalista.

Tomar um determinado Estado do imperialismo, como fizeram os guerrilheiros do Nepal alguns anos atrás, pode não surtir o efeito pretendido se não se mudarem as estruturas sociais e políticas para realmente romper com a colonialidade. $O$ machismo conservador é um dos obstáculos. Sem essa percepção da necessidade de rompimento com a colonialidade imperante, o imperialismo rapidamente se rearranja e retoma todos os espaços, retomando a frente na iniciativa, como ocorreu naquele país (SANTOS, 2010).

Numa disputa militar estratégica de tomada do poder, as forças imperialistas são infinitamente maiores. Certamente, o Estado receberá apoio dos maiores exércitos do mundo na luta pela manutenção do status quo colonial. Mas, se houver uma iniciativa de mobilização da sociedade e compreensão da necessidade de rompimento com a colonialidade reinante, outros e novos componentes podem ser aderidos à questão (GROSFOGUEL, 2010) da defesa do interesse nacional.

Os países do norte utilizam-se de discurso afirmativo dos direitos humanos, mas praticam-nos somente em defesa de interesses minoritários de cunho político e econômico monopolistas, ainda assim, dentro dos outros países. Humanidade, povos e etnias, direitos humanos são conceitos lançados à mão para privilegiar e destacar interesses privados monopolistas.

Dignas são todas as pessoas, pelo só fato de pertencerem ao gênero humano (MARTINS-COSTA, 2003). Este é o ponto central da dignidade humana. Dignidade pode ser conceituada como um mínimo existencial suficiente para que o humano 


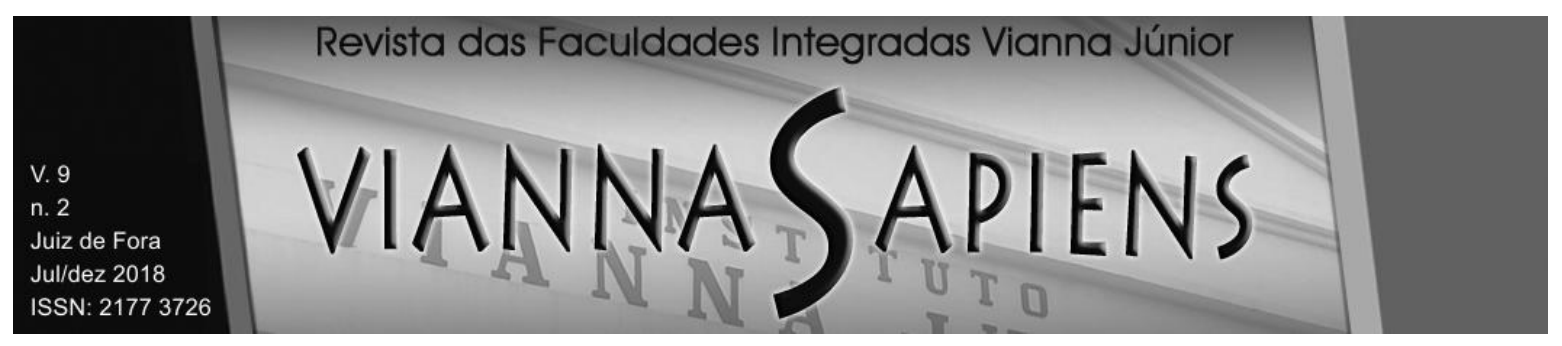

desenvolva potencialidades e tenha acesso a direitos. Seu conteúdo de vida digna não se deve definir, já que é conceito subjetivo, variando conforme a cultura de cada povo. Tanto o genocídio quanto a pobreza são formas de violação dos direitos humanos, limitam as possibilidades de existência do indivíduo e do povo do país (MAGALHÃES, 2010. Genocídio como forma de destruição de minorias raciais e populações subjugadas por meios e métodos, tais como trabalhos em condições desumanas (SCHABAS, 2016, p. 137).

A dignidade é fruto de autoconstrução ou autonomia e realização em sociedade ou alteridade. Logo a dignidade não é algo "dado" pelo Estado, pela ciência ou pela política, ao contrário, é uma busca de autorrealização construída no curso do tempo (STANCIOLI, 2010).

Dignidade é um conceito a que todos recorrem, porque pode-se vê-lo com olhos do norte ou do sul. É preciso entender a outra cultura com o olhar dela ou não a entenderá e, dialeticamente, é preciso entender como titular de uma cultura genuína e original que tem valor e que deve ser experimentada como caminho para o desenvolvimento de um povo com autonomia e soberania (SANTOS, 2001).

A maneira brutal com que Hernan Cortez( 1986) em poucos anos dizimou o Império Asteca de 500 anos em busca de seu ouro pode ser comparada à cena dos soldados americanos urinando sobre os corpos de guerrilheiros afegãos mortos em combate, filmados e mostrados a todo o mundo, como se piratas sem ordem nem lei fossem, em clara afronta a princípios éticos e morais daquele povo e de qualquer outro povo que fosse.

A dignidade atua em conjunto com outros princípios e direitos fundamentais, tais como, liberdade, autodeterminação, honra, igualdade, etc. Os crimes contra a humanidade trouxeram a lume o princípio da dignidade da pessoa a partir do Tribunal Penal Internacional. A dignidade da pessoa humana precisou ser consagrada positivamente. Assim, diversas Constituições nacionais passaram a adotá-lo nesta nova compreensão.

A humanidade, todos os seres humanos a têm igualmente, sejam eles negros, judeus, muçulmanos, mulheres, árabes, índios ou brancos. E a desproteção a esta 


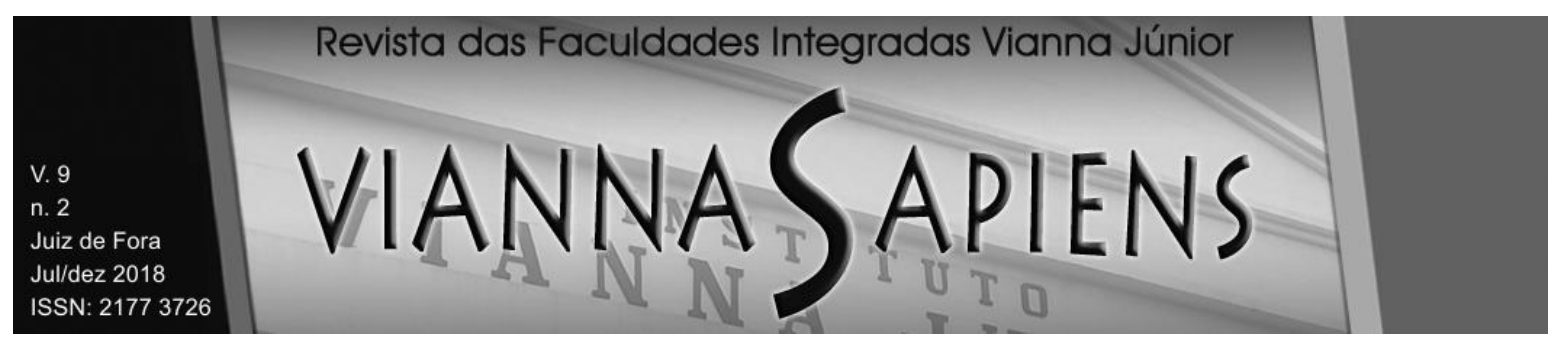

humanidade leva à discriminação, racismo, exclusão social, à negação de direitos. A subalternidade do pensamento subalterno, contraposto ao pensamento eurocêntrico, deve se afirmar em toda sua extensão para falar e ser ouvido, deixando de ser subalterno.

O que se percebe é que esse conjunto de idéias sobre dignidade e humanidade individual e coletiva do povo, ao se observar que o Brasil foi colônia por quase 400 anos e, depois desse tempo todo, permaneceu como colônia de outras metrópoles todo o século $X X$ até os dias atuais, não é facilmente percebido, nem mesmo pela classe governante acostumada e feliz em sua condição colonial, em sua colonialidade.

Um presidente da república que é informante dos países do norte antes de ser eleito, descoberto em suas intenções, deve ser deposto por indignidade para o cargo. Mas, nos países do sul, isso é a normalidade e tal fato amplia seu apoio e consideração, a ponto de o Tribunal, que deve examinar a licitude da sua campanha presidencial, deixar de fazê-lo sob argumento de a governabilidade precisar ser garantida em detrimento da aplicação da justiça.

Humanidade, dignidade e direitos do homem são conceitos abstratos que todo habitante da terra deve exercer. Nuns lugares de um modo, em outros de modo diferente. Observar, como orienta Santos, cada civilização a partir de seu local de observação. Olhar o mundo dali, entender esses conceitos sendo manejados e praticados. A dignidade do povo do Brasil está sendo negligenciada há séculos e no século XXI.

Dignidade tem valor em si. É fim, não é meio, como determina a Constituição de 1988 e a previsão inédita de princípios fundamentais. A autonomia é a base da dignidade humana e de qualquer criatura racional, como ainda de todo o povo do país (PIOVESAN, 2012).

A dignidade de um povo pode ser vilipendiada, quando os interesses dos países do norte são arranhados ou turbados. A destituição de presidentes sob acusação de infringência à regra constitucional, justificam-se por todos os argumentos ao alcance da mão. Para garantir a aprovação de medidas jurídicas e 


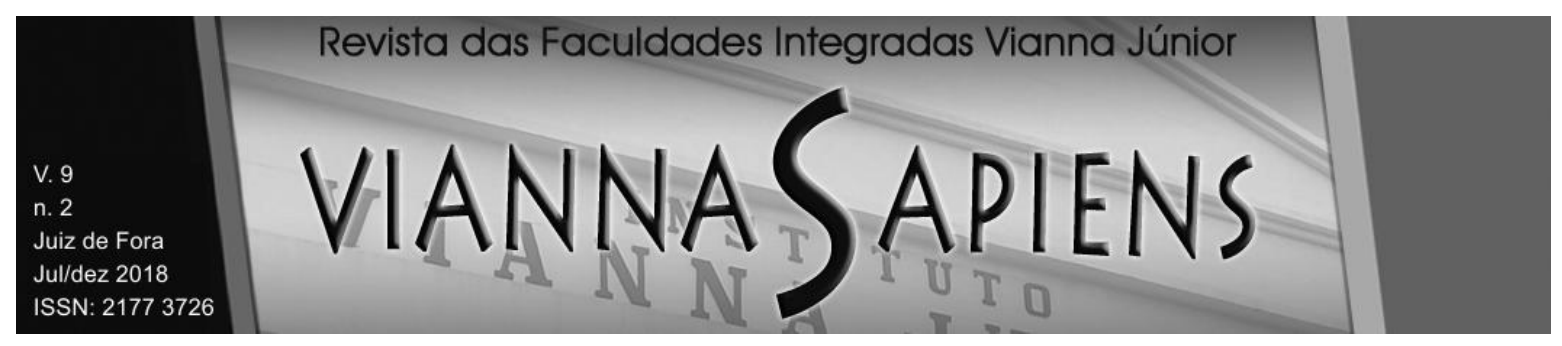

econômicas previamente pensadas para carrear os recursos naturais do país em favor de interesses externos, a classe política demonstra uma atuação de servil intermediária dos usurpadores dos recursos naturais do país, que são os mesmos há 500 anos.

Após as grandes navegações e o surgimento do capitalismo e acumulação de riquezas a prosperidade do capitalismo europeu e americano do norte tem sempre como origem a pilhagem, o massacre, a escravidão dos índios e povos americanos, dos africanos e asiáticos. Ouro e prata enlouquecem os capitalistas, o dinheiro os fascina (GALEANO, 1986). Os incas foram trucidados porque idolatravam o Deus Sol através das peças de ouro. Os espanhóis os sacrificaram por idolatrarem o ouro das máscaras incas em nome do seu deus, lendo-se Dussel com Las Casas e Poma de Ayala (DUSSEL, 2010).

Quando se enfocam os conceitos de dignidade e pessoa, tem-se um arroubo inicial de utilizá-los segundo regras postas pela visão do norte conceitual de democracia e direitos humanos, como se donos desses conceitos fossem os países do norte, originados na criação da ONU. Basta, para que se subverta a regra, a lembrança da Guerra do Ópio (GARAUDY, 1978) que impôs à China o comércio e uso do ópio, em benefício de franceses, alemães e ingleses; ou os feitos americanos e franceses contra o povo do Vietnã e tantos outros, tais como Afeganistão, Iraque e Líbia.

Os países do norte vangloriam-se da criação desses conceitos, sem tê-los criado e sem praticá-los para si contra seus contendores. Deveriam compreender-se como alguns entre muitos membros da família humana da terra, mas não o compreendem ainda (SANTOS, 2010).

Mas tal percepção não está presente entre os povos e classes dirigentes no mundo e no Brasil.

Porque o horizonte das revoluções modernas colapsou ou porque o nosso tempo se indecide em ser demasiado prematuro para ser prérevolucionário ou demasiado tardio para ser pós-revolucionário? Assumir plenamente o nosso tempo significa reconhecer esta 


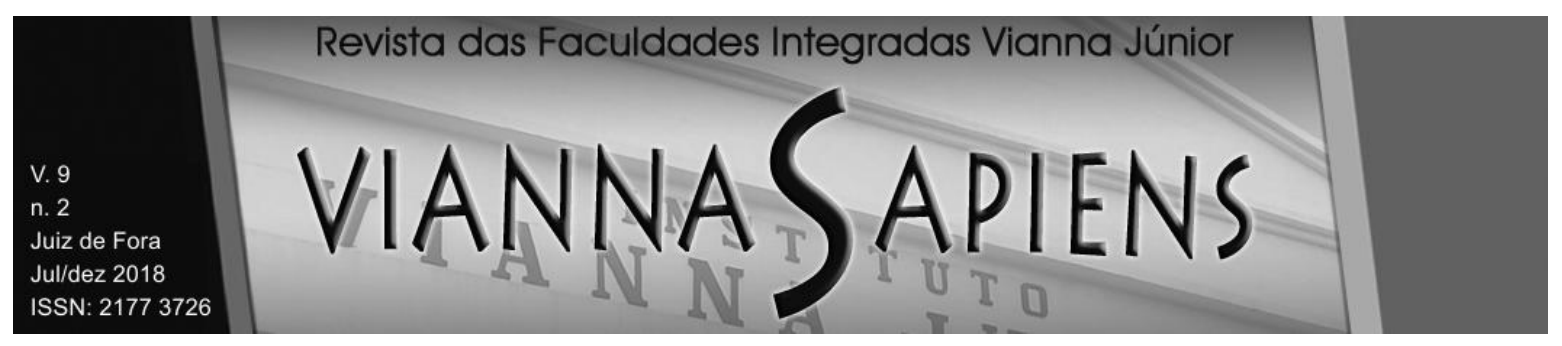

desproporção e proceder a partir dela. Significa, por outras palavras, radicalizar a rejeição e procurar as alternativas a partir da radical incerteza destas (SANTOS, 2010, p. 532).

\section{BUSCAR OUTRO RUMO}

A sistemática despolitização dos direitos humanos é um poderoso instrumento ideológico e de alienação. A despolitização (via televisão e internet) é uma ideologia recorrente utilizada pelo poder econômico para manter sua avassaladora hegemonia. Uma expressão que ideologicamente o poder insiste em mostrar como apolítica é a expressão "Direitos Humanos" (MAGALHÃES, 2010).

Democracia, mundialmente falando, é 0 direito de o povo escolher autonomamente sua forma de Estado, seu sistema de governo e as garantias de direitos coletivos e individuais. Existem outros modos de perceber um novo modo de compreensão do espaço territorial de convivência entre o povo e o governo em que se compreende de novas formas esses conceitos.

Os modelos novos propostos pelo Estado Plurinacional são outra forma de ver tais questões. Não são somente formas teóricas, mas práticas, à medida que dois Estados nacionais, Equador e Bolívia, entre outros, as têm buscado elaborar e desenvolver. Num modelo de democracia participativa a mais plena possível, segundo o interesse de todos (MAGALHÃES, 2012).

É um modelo de proposição diferente, novo, que responde a diversas questões candentes e abre outros questionamentos. Se vivemos num mundo comandado pelo capitalismo, se queremos outras formas de governança, devemos aprofundar a compreensão de que todos os povos, dentro de uma mesma unidade nacional, são legítimos para reivindicarem direitos quanto aos recursos naturais daquele território.

Todos os integrantes de um grupo nacional ou plurinacional são legítimos, mas se forem autônomos entre si poderão ser cooptados pelo imperialismo e terem seus direitos vilipendiados por quem sabe fazer isso há mais de 500 anos. Esta a 


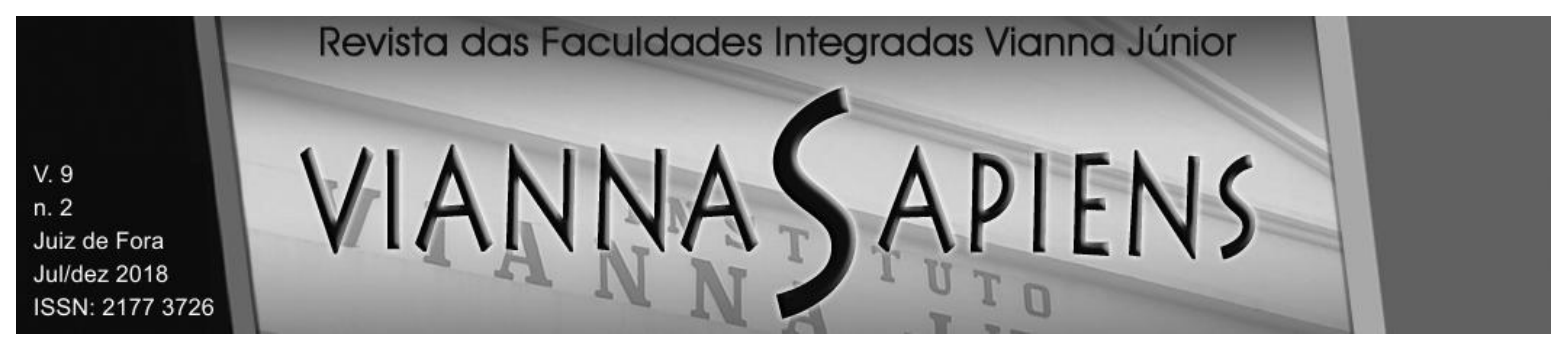

principal denúncia de Orlando Vilas Boas (2017) sobre a terra yanomami na "cabeça do cachorro" no Amazonas.

No mundo da modernidade eurocêntrica, os países estão divididos geográfica e politicamente em fronteiras. Fronteiras foram criadas em todos os continentes forjadas pelo interesse econômico do capitalismo, fronteiras que diversos povos não compreendem e não têm nelas alguma referência, tal como os beduínos africanos (DEMANT, 2008, p. 91-92). Porém, esses marcos limítrofes, alguns de séculos, vêm sendo observados quando se fala em propriedade dos recursos naturais e minerais.

As fronteiras admitidas pelos países há cerca de trezentos anos ou menos, devem ser respeitadas no tocante à autonomia de cada povo dentro das linhas geopolíticas. A diversidade a ser assegurada e incentivada do povo pode garantir direitos internos e internacionais deste país. Do contrário, estaremos todos nas mãos dos instintos selvagens dos países do norte.

A presença do capital financeiro internacional dentro de cada país num dia e fora no outro dia deve ser proibida de alguma maneira. A remessa de capitais empobrecendo uns países e enriquecendo outros deve ser disciplinada, pelo bem de todos.

Ao observarmos os povos africanos, como exemplo, com seus diversos grupos étnicos, línguas e dialetos em grande número, podemos perceber que foram constituídos estados artificiais por sobre identidades culturais distintas e até mesmo conflitivas. Nalguns casos, como nos países no norte africano, a delimitação de fronteiras geométricas, retilíneas denotam sua artificialidade. É certo que os povos nômades e outros nunca conheceram nem reconheceram as fronteiras que os países do norte criaram no século XX. Mas essas fronteiras se consolidaram na esfera internacional e os países do sul podem reivindicar seus direitos dentro destas mesmas limitações reconhecidas internacionalmente.

O movimento de criação pela ONU de países com divisas territoriais impostas pelos colonizadores não surtiu o efeito que desejaram (DEMANT, 2008). Pensaram que, agindo assim, os países e as regras jurídicas de cada povo se impregnariam da visão ocidental. Este era e sempre foi o desejo de uniformização jurídica mundial, 


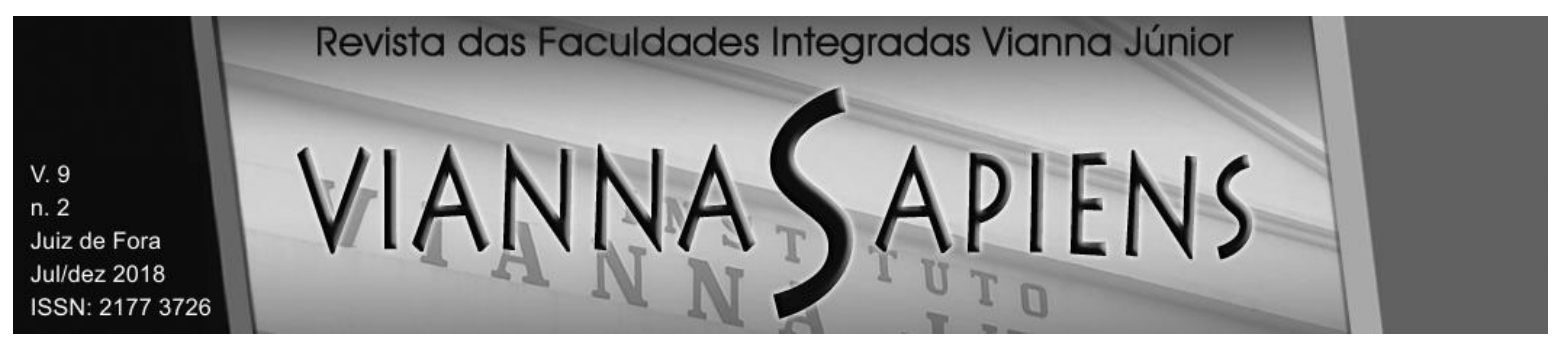

demonstrando a arrogância da cultura eurocêntrica (AZEVEDO, 2008). Queriam que todos pensassem como eles, os líderes europeus da ONU, porque eles pensam que têm compreensão mais civilizada e correta que todos os demais povos do planeta (KI-ZERBO, 2010).

Toda essa existência de exploração e miséria ensejou a discussão e aprovação na esfera das Nações Unidas da Carta Africana dos Direitos Humanos e dos Direitos dos Povos ao desenvolvimento de 1981.

Muito controvertido é o direito ao desenvolvimento, declarado no artigo 22. A proposta para o reconhecimento deste direito foi feita pela primeira vez em artigo doutrinário em 1972. A Assembleia Geral das Nações Unidas, em uma Declaração de 4 de dezembro de 1986 (A/RES/41/128), "reconhecendo que o desenvolvimento é um amplo processo econômico, social, cultural e político, que objetiva a melhoria constante do bem-estar de toda uma população e de todos os indivíduos, na base de sua participação ativa, livre e consciente no desenvolvimento e na justa distribuição dos benefícios dele resultantes", afirmou que "o direito ao desenvolvimento é um direito humano inalienável, por força do qual todas as pessoas humanas e todos os povos estão autorizados a participar do desenvolvimento econômico, social, cultural e político, para ele contribuir e dele fruir, desenvolvimento no qual todos os direitos humanos e todas as liberdades fundamentais podem ser plenamente realizados" (art. $1^{\circ}$ ) (COMPARATO, 2004, p. 394-395).

Por certo a delimitação forçada de muitos Estados nacionais não contribuiu para a democratização dessas localidades, em vista de que as nações colonialistas não o desejavam. Pretendiam, sim, manter o jugo sobre cada um dos territórios novel independentes (COMITINI, 1980, p. 63).

É importante destacar o caráter artificial dessas novas colônias, Estados inexistentes, inventados com base no acordo Sykes-Picot. O mundo árabe tinha suas divisões internas: entre agricultores e citadinos; entre abastados effendis (proprietários) e mercadores e um proletariado urbano e rural faminto; entre muçulmanos, judeus, cristãos das várias congregações e seitas; entre nacionalistas e aqueles que continuavam ligando sua identidade coletiva a critérios religiosos. Havia também dialetos e costumes diferentes. Entretanto, nada havia preparado o terreno para a partilha de 1920. As novas 


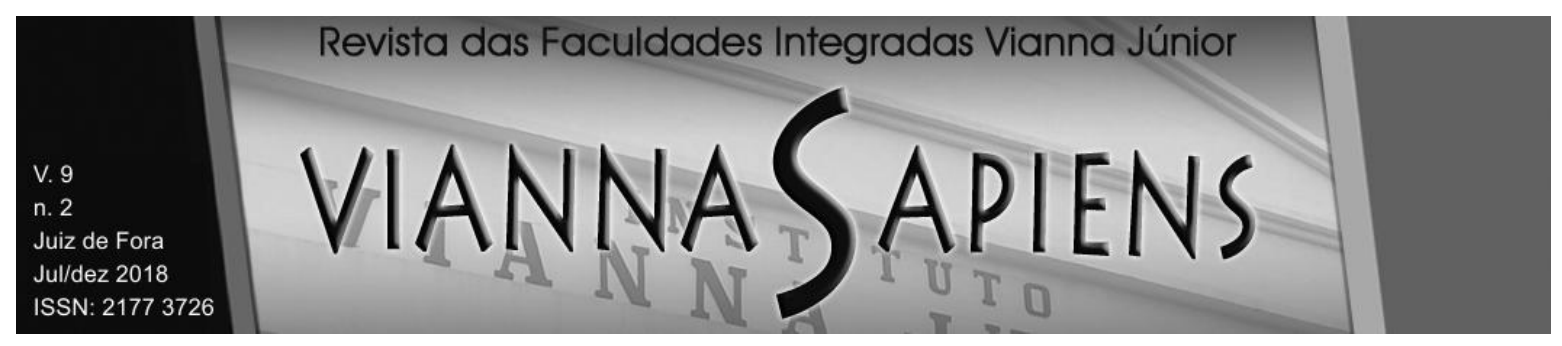

fronteiras cortaram em pedaços o que fora uma sociedade milenar, com uma economia comum, e que passava, justamente, pelo processo de conscientização de possuir um destino comum (DEMANT, 2008, p. 91-92).

Mas quanto às fronteiras brasileiras, talvez por sua grande extensão territorial ou talvez por terem sido dizimados milhões de habitantes nativos, já que se estima a população antes da chegada dos portugueses em 4 milhões de nativos, essas contradições e conflitos não têm sido observadas pela história oficial do Brasil. Certamente existiram conflitos, pois a população nativa decaiu em $80 \%$ daquela originária, a partir do profundo preconceito, arrogância e violência do colonizador com os povos originários, fatos que sequer foram relatados na história. Mas, de modo geral, as fronteiras externas do Brasil parecem não receber questionamentos internos ou externos.

O sistema político mundial admite as fronteiras somente quando há interesses econômicos que as sustentem, pois, quando não se quer respeitá-las, atuam por invadi-las, como pode estar vindo a ocorrer na Amazônia, com a ocupação interna, sem que os governantes tomem medidas efetivas de proteção.

O processo colonial é profundamente arraigado nos conceitos e posturas de todos os povos da terra que o viveram. A chegada do colonizador já se mostra como um novo paradigma para os povos originários que não os imaginavam. Em seguida, a destruição da cultura preexistente e a inferiorização do povo marcam profundamente suas tradições. Depois passam à cooptação dos nativos e à degradação de uma unidade cultural construída. Esse processo legitimado pela violência e ausência ética e moral do colonizador, por estar em terras longínquas, submete o nativo que se sente inferiorizado e é incentivado a sentir-se assim (DUSSEL, 1993)

A incompreensão e a oposição ao processo de ser colônia é violentamente expurgado daquela sociedade. Por exemplo, na Inconfidência Mineira, como em milhares de outros pelo mundo, ocorre o encobrimento surdo da incompreensão de ser colônia a poder das armas. Junto das armas a cultura dominante toma lugar 


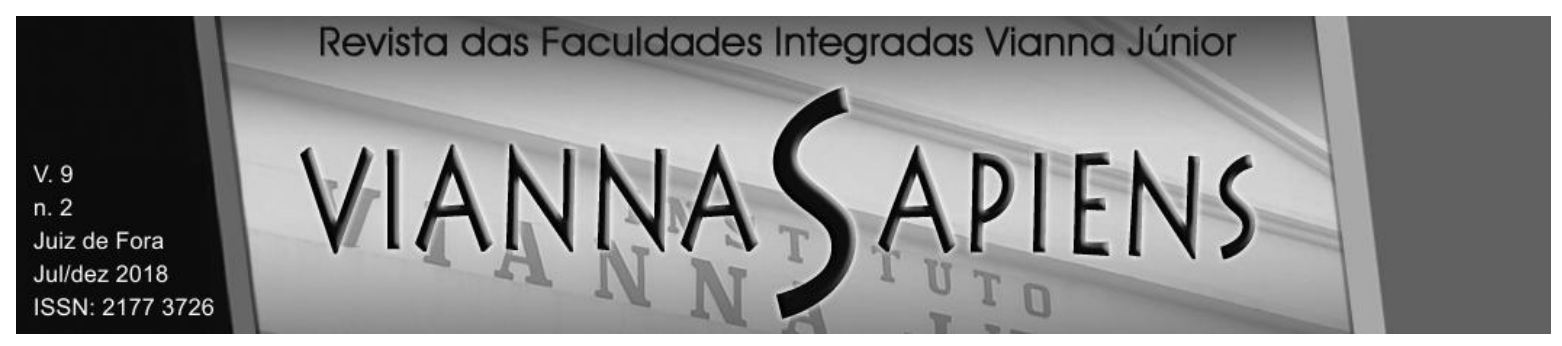

central, seus preconceitos e inverdades viram normas de conduta. A incompreensão de ser colônia desaparece do seio do povo no correr das décadas por meio da linguagem social do colonizador e os poderosos corrompem-se para se acomodarem junto ao poder.

O des-cobrimento da incompreensão de ser colônia, assim, é a colocação a descoberto desse pérfido sistema que abafa as liberdades e violenta a compreensão de ser colônia até sua asfixia. Este deve ser um processo dentro da libertação do povo da sua condição de colono, da exposição de suas fragilidades e méritos na construção estratégica de suas forças nessa luta de independência que virá em seguida. $O$ encontro de sua identidade integral.

\section{A BUSCA DA IDENTIDADE A MAIS INTEGRAL POSSÍVEL}

No centro da questão está a compreensão da identidade integral que temos de lutar por alcançar. Os países ocidentais, porque aqui incluídos Portugal e Espanha como os impérios do século $\mathrm{XV}$, com a burguesia na vanguarda, criaram o movimento das Declarações de direitos e as Constituições nacionais. A origem dessa criação foi o modelo político-econômico que se queria vencer então: a monarquia e o absolutismo concentradores da economia que vigorara na Europa por mais de mil anos e a concentração de terras, riquezas e poder político nas mãos de poucos (PACHUKANIS, 1977).

A burguesia tomou o poder no Ocidente e de lá nunca mais saiu sempre a propagandear o Estado mínimo, contraposta aos movimentos sociais em buscar outra vertente para um Estado social. No Brasil e por todo o mundo são permanentes os conflitos entre 0 interesse público e 0 interesse privado, que Grosfoguel considera dicotomias insuficientes em vista da necessidade de reconhecimento de uma identidade maior do povo do país (2010).

Essas mudanças não ocorreram em algumas regiões da terra, tais como no Oriente e na África, que tinham outra base filosófica apoiada no islamismo. Hoje 


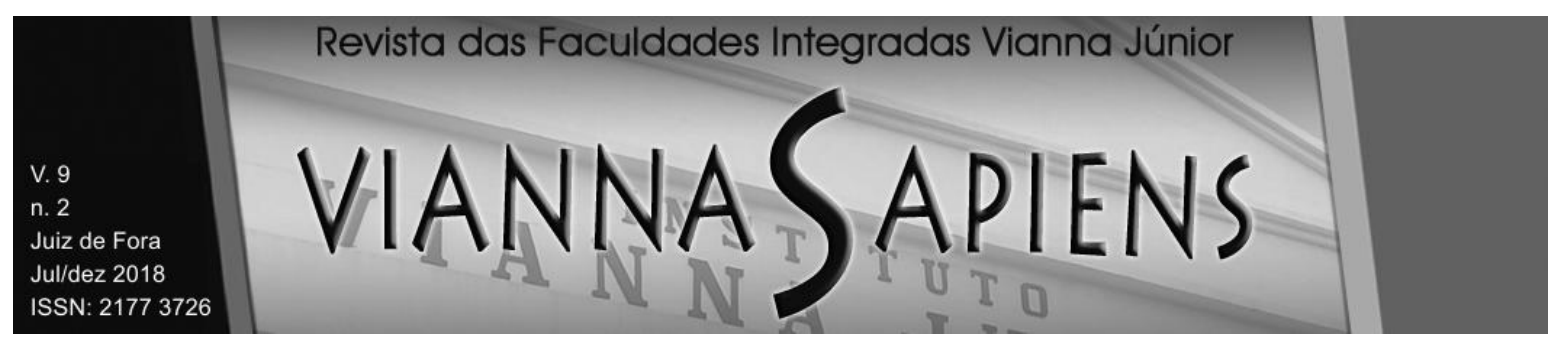

parte crescente dos países do mundo adota o islamismo como regra religiosa e política, por exemplo.

Porém, é preciso resgatar a dignidade da pessoa e do povo. Se o povo do Brasil não perceber sua condição de colonialidade e não confrontá-la, permanecerá no mesmo lugar a ele reservado no sistema mundial contemporâneo desejado pelas metrópoles. Mas percebê-la, o que não é fácil, reconhecer-se nela, opor-se a ela, recusá-la para si, e sair em busca de outro posicionamento cultural, político e social, por isso mesmo também econômico, permitirá abrirem-se novos caminhos e outras opções de posicionamentos ideológicos ante os países do norte.

A situação política e econômica brasileira, mesmo que tutelada há séculos, é responsabilidade dos brasileiros, a quem é posta a condição de perceber a conjuntura mundial e regional, refletir sobre ela, confrontá-la e sair em busca de alternativas.

Observando-se o quadro político brasileiro atual e a extensão da corrupção instalada em todos os segmentos sociais de poder e na sociedade, pode-se imaginar a dificuldade de modificação dessa situação aflitiva, em vista de que os países do norte tudo farão para impedir a modificação da ordem social e política dentro do país.

Para isso, os segmentos sociais devem atuar buscando seu direito à vida digna na ausência de afetação de inferioridade, de vassalagem cultural (música, cultura, cinema) e interesses dos países do norte. Devem recusar o status de celeiro e produtor de commodities (matérias-primas) do desenvolvimento e da acumulação de riquezas daqueles e construir sua própria proposta de desenvolvimento sustentável. Os países mais desenvolvidos fizeram isso em suas lutas por independência e foram aplaudidos pelas suas gerações por assegurarem seu desenvolvimento soberano.

Não há porque persistir na postura de aceitação da estratégia global de dominação e expansão colonial estabelecendo uma hierarquia de conhecimento superior e inferior e de povos superiores e inferiores. 


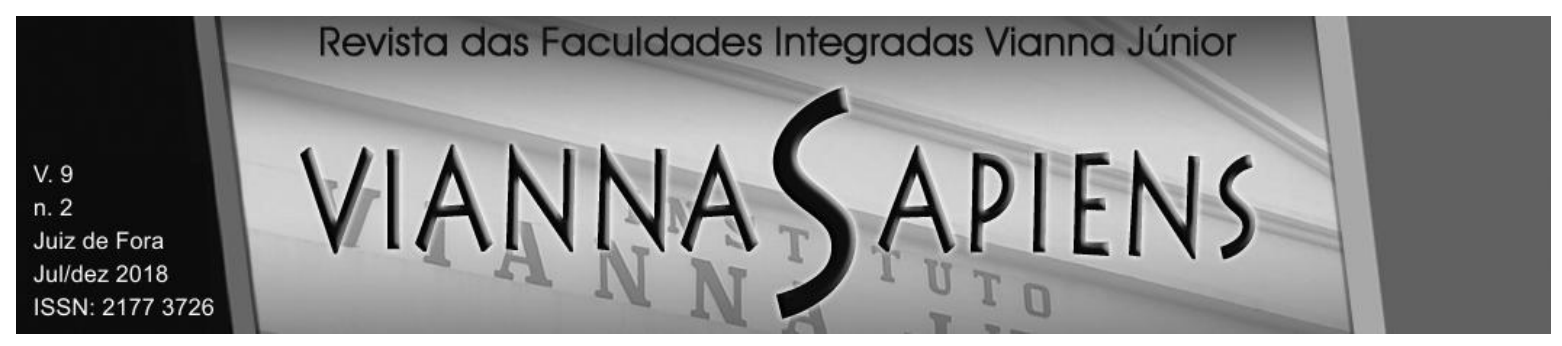

Passamos da caracterização de 'povos sem escrita' do século XVI, para a dos 'povos sem história' dos séculos XVIII e XIX, 'povos sem desenvolvimento' do século $X X$, e, mais recentemente, 'povos sem democracia' do século XXI. Passamos dos 'direitos dos povos' do século XVI (o debate Sepúlveda versus de las Casas na escola de Salamanca em meados do século XVI), para os 'direitos do homem' do século XVIII (filósofos iluministas), para os recentes 'direitos humanos' do século XX. Todos estes fazem parte de desenhos globais, articulados simultaneamente com a produção e reprodução de uma divisão internacional do trabalho feita segundo um centro e uma periferia, que por sua vez coincide com a hierarquia étnico-racial global estabelecida entre europeus e não-europeus (GROSFOGUEL, 2010, p. 461).

Não há porque Petrobras, Embraer, pré-sal, os minérios de Roraima, Amapá, Amazonas, Pará e Minas Gerais, o ouro de Serra Pelada e outras regiões, o nióbio, a biodiversidade amazônica, a água potável, não serem dirigidos e administrados por interesses nacionais em benefício de toda a coletividade, como determinou a Constituição de 1988.

Mas, para modificar esse estado de coisas, deve-se, talvez antes de tudo, construir novas relações sociais. Não se pode manter a maioria da população como cidadãos de segunda classe, como atualmente ocorre. É preciso de modo radical distribuir a todos os cidadãos condições iguais de trabalho e subsistência, atuando firmemente na igualdade racial, de gênero e de classe, conforme diz o artigo $5^{\circ}$ da Constituição Federal do Brasil, erradicando a transferência de riqueza e capital dos países do sul para o norte. Depois de séculos de exploração do norte sobre o sul, numa acumulação de riquezas sem precedentes, deve haver uma redistribuição digna. Uma nova ordem mundial deve ser debatida e buscada pelos povos explorados. O atual estado de coisas não deve prosperar.

O encontro da identidade integral é um processo que os países do sul devem viver para se perceberem independentes e autônomos entre iguais no mundo atual. Para isso, também precisam alcançar sua dignidade individual e coletiva. Festas populares, manifestações culturais e políticas, reivindicações de direitos, luta e conquista desses bens são alguns dos passos que devem ser experimentados e 


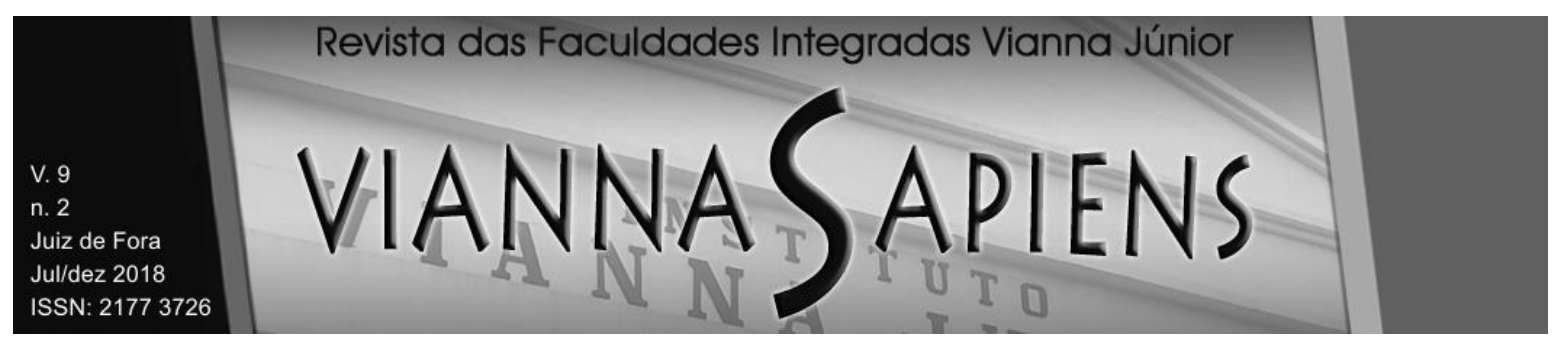

vividos em plenitude como outros povos do mundo já experimentaram com êxito. Não sugerimos poesia e sonhos, mas a luta e a violência revolucionária de Hanna Arendt como meios de abertura de espaços para a claridade da identidade e autorreconhecimento dos povos em meio ao mundo capitalista.

Desde as grandes navegações, a estratégia dos países capitalistas centrais para permanecerem poderosos e dominantes consiste em ampliar os mercados de captação ou exploração de riquezas em todos os cantos do mundo. Esses movimentos ferem interesses soberanos dos povos e, por isso mesmo, realimentam constantemente a máquina de guerra que sustenta todo este cenário mundial (HOBSBAWM, 1997).

O século XIX foi o da Revolução da Indústria, o século XX da necessidade da exploração dos recursos naturais de todos os países do hemisfério sul pelos países do norte, ceifando sua população de alimentos e conforto, sob a firme, resoluta e violenta supervisão do FMI (GALEANO, 1986), Banco Mundial e OTAN (GROSFOGUEL, 2010, p. 486).

A invasão do Iraque (como da Líbia), um enorme, rico e desenvolvido país asiático, de riquíssima história e acervo da Humanidade, sob o argumento de destruição das armas químicas que o país possuía e a defesa da população civil contra seus próprios governantes, o que não se verificou, foi medida meticulosamente planejada para o fim de ampliação de mercados de petróleo sob a direção dos países exploradores.

Se o governante não cede facilmente aos comandos do capital financeiro e monopolista mundial, monta-se, então, a versão que será divulgada mundialmente. Aponta-se que o governo do país desrespeita os direitos individuais dos cidadãos e os direitos humanos. A partir daí a imprensa mundial bate diariamente nessa tecla. Cada dia num editorial diferente. No mundo e no Brasil todas as redes de comunicação veiculam a mesma notícia. O cidadão comum de todas as classes sociais desinformadas, acríticas, seguidoras ávidas de programas televisivos de baixíssimo nível, que visam à alienação geral, começa a pensar que isso é verdade e que se trata de fatos reais (PIMENTA, 2017). 


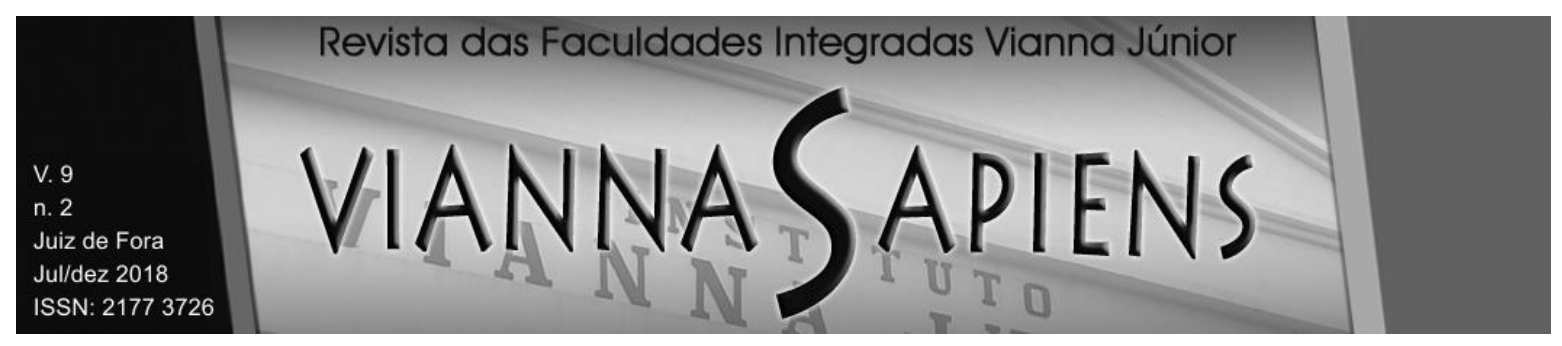

Em seguida, afirmam tratar-se de governo despótico e que lá está o governante a desrespeitar as regras definidas para seguir. Basta que os correspondentes internacionais desembarquem no país, produzam suas matérias jornalísticas de alto nível e a derrubada do poder é questão de tempo, diante do advento das redes mundiais de computadores, internet, fakenews e matérias plantadas estrategicamente.

Quanto às armas químicas e nucleares? Era só um detalhe para confundir a todos. O presidente do país mais poderoso da Terra declara em seu último discurso ao mundo "que não era verdade. Não foram encontradas as armas químicas, mas o resultado final foi plenamente atendido" (FRANCISCO, 2013, p. 73).

\section{CONCLUSÃO}

Nesse novo tempo, somente deve ser permitida a remessa de capitais para o exterior na troca por benefícios sociais similares ou de outra ordem, segundo o interesse nacional, coletivo e não individual de poucos, banida de modo veemente e radical a corrupção.

Nessa orientação de igualdade anticolonial, deve ser instituída nova política ambiental, por exemplo, que proteja o meio ambiente de modo efetivo, permitida a utilização sustentável com a condenação dos responsáveis pelos crimes ambientais e humanos perpetrados no país, como o ocorrido na região de Mariana em Minas Gerais pela empresa Samarco.

O povo quer ver os corruptos presos e condenados a penas de reclusão e pecuniárias, para devolução dos recursos que pertencem a todos aos cofres públicos nas investigações em andamento. Mas, nos crimes da Samarco, muito mais graves que o desvio de verbas públicas, posto que deixou 19 mortos, ainda ninguém foi preso, nem nenhuma condenação exemplar. Silêncio total.

O destinatário do direito e das normas deve ser tratado como membro livre e igual de uma comunidade de sujeitos de direito e tratar igualmente as pessoas 


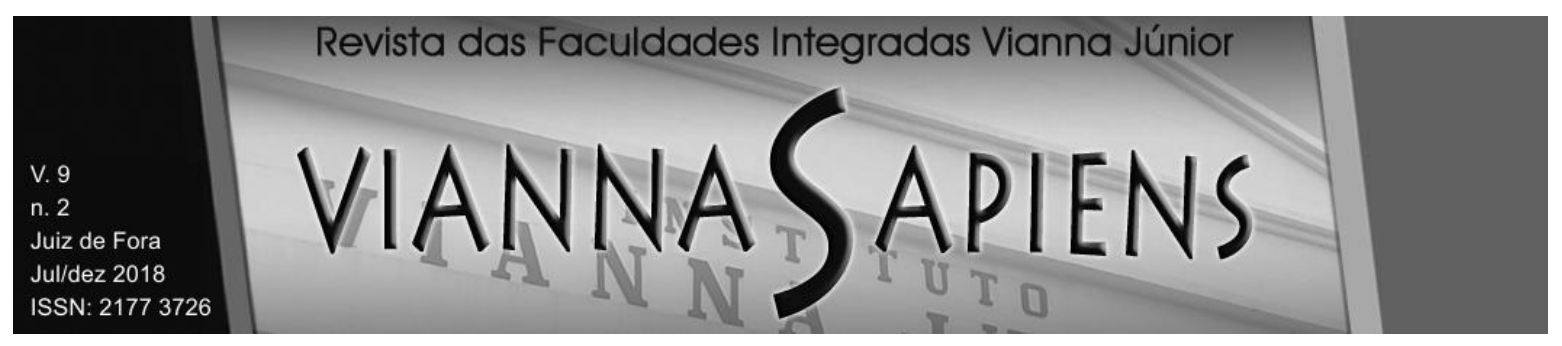

jurídicas em sua integralidade. Exige-se igualdade de tratamento, que inclui a igualdade de aplicação do direito, isto é, igualdade das pessoas perante a lei sem subterfúgios, o que equivale, também, ao princípio amplo da igualdade do conteúdo do direito, segundo o qual aquilo que é igual sob aspectos relevantes deve ser tratado de modo igual e aquilo que não é igual deve ser tratado de modo não igual.

Por tudo que se observa no cenário mundial diante da sede, cada dia maior, e volúpia capitalista ante os países do sul, é preciso partir para se construir novas relações sociais como forma de se contrapor a este estado de coisas. Não é um processo novo. É um processo já realizado em alguns países, mas nunca realizado no Brasil, nem autorizado pelo colonizador e inimaginado pela colonialidade do colonizado.

Romper com a colonialidade será duríssimo, conturbado e disputado entre os segmentos do poder colonizado que não queiram deixar o poder e os diversos segmentos autorreconhecidos da sociedade e do povo desejosos de assumir 0 poder. Superá-la não estará na ordem do dia enquanto não envolver uma parcela significativa da população, tão significativa que imporá novas regras nas relações norte-sul entre este país e os demais.

Alcançar uma nova construção social que vise erradicar a visão de se manter a maioria da população como cidadã de segunda classe, como ocorre no mundo todo. É preciso, do modo mais radical possível, que todos os cidadãos, ou parte ponderável, se reconheçam em condições iguais de trabalho e subsistência, atuando firmemente na luta e conscientização de todos pela igualdade racial, de gênero e de classe para empoderar a população como um todo.

Mas é certo que este será um processo em que a população deve tomar em suas mãos essas novas perspectivas. Romper com a alienação e o sentimento de inferioridade e de ser colônia é processo que deve partir da consciência nacional, como em outros países tem ocorrido.

Isso para que nalgum momento seja desejado por essa mesma população erradicar a transferência de riqueza e capital do sul para o norte como há 500 anos e investir todos os recursos daí advindos no próprio desenvolvimento sustentável. 


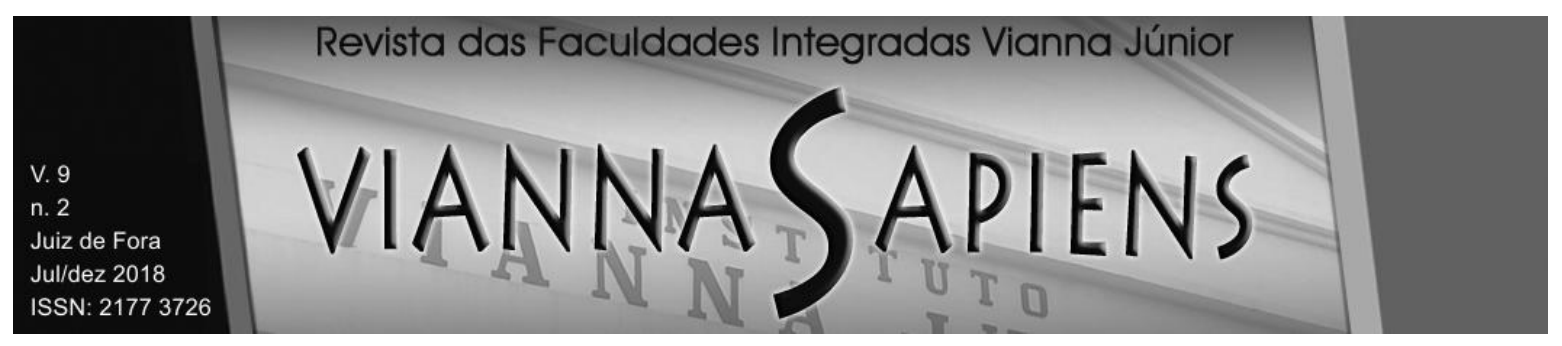

É necessária uma nova ordem mundial que distribua riquezas entre vendedores e compradores, não entre exploradores e explorados e investimentos mundiais na redução da pobreza e da fome no sul, pois somente assim a economia mundial se distribuirá em favor de todos os povos.

Mas, para alcançarem esta e outras metas, precisam mudar a concepção sobre si e sobre os parceiros do norte e passar a vê-los como parceiros do norte, modificando a posição de inferioridade colonial que permite e aceita o papel de produtores de toda a matéria prima mundial e não se beneficiarem dela de modo pleno.

O Produto Interno Bruto (PIB) brasileiro em 2016, em constante crescimento, foi de $R \$ 6$ bilhões (IBGE, 2017). As reservas minerais do subsolo brasileiro somam alguns trilhões de dólares, centenas de vezes esse valor anual. O brasileiro não vai em busca do seu progresso e persevera em permanecer como colônia de remessa de matérias-primas aos países do norte já por 500 anos, porque não se reconhece como um dos membros em igualdade de condições, como todos os países do mundo debaixo de profunda corrupção do poder.

Aqueles que entendem como sua a tarefa de combater o entreguismo das riquezas naturais e minerais do país devem buscar soluções para vencer estes enormes obstáculos que são os interesses internacionais acima de tudo. As armas dessa luta podem estar nas mãos dos segmentos sociais que podem ir se conscientizando de sua personalidade cidadã, da usurpação de seus direitos e, no reconhecimento de sua identidade como povo e pessoa, afastando a todo custo a alienação, caminhar em direção a uma saída desta incômoda compreensão secular de subalternidade ante os países do norte.

A mudança da postura do Brasil no teatro das nações fará bem a todo o sistema mundial das nações. Fará bem ao Brasil e aos brasileiros, mas também fará bem aos parceiros dos países do sul e demais países, que terão um parceiro mais firme e equilibrado e em melhores condições de aprofundar melhores negócios, como prestará excelente suporte a todas as nações do sul na compreensão do seu lugar e do seu espaço no mundo do século XXI. 


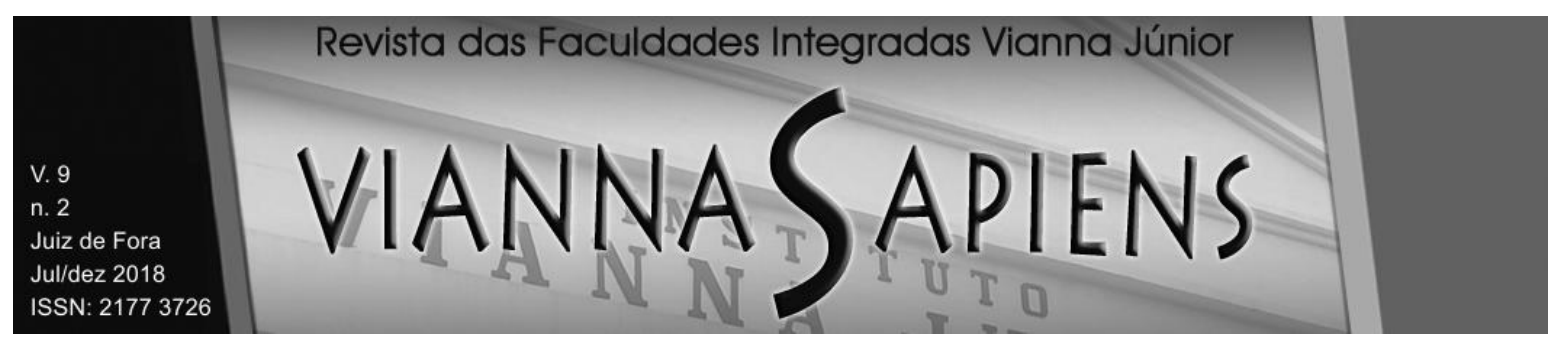

\section{REFERÊNCIAS}

AGAMBEM, Giorgio. Profanações. Tradução Selvino J. Assmann. São Paulo:

Boitempo, 2007.

ARENDT, Hannah. A condição humana. Tradução de Roberto Raposo. Posfácio Celso Lafer. 10.ed. Rio de Janeiro: Forense Universitária, 2007.

AZEVEDO, Antônio Junqueira de. Crítica ao personalismo ético da constituição da república e do código civil: em favor de uma ética biocêntrica. In: AZEVEDO, Antônio Junqueira de (coord.). Princípios do novo código civil brasileiro e outros temas. SP: QuartierLatin do Brasil, 2008.

CANOTILHO, José Joaquim Gomes. Direito constitucional e teoria da constituição. Coimbra: Almedina, 1998.

COMITINI, Carlos. África arde: lutas dos povos africanos pela liberdade. Rio de Janeiro: Codecri, 1980.

COMPARATO, Fábio Konder. A afirmação histórica dos direitos humanos. 3. ed. São Paulo: Saraiva, 2004.

CORTEZ, Hernan. A conquista do México. Tradução de Jurandir Soares dos Santos. 2. ed. Série: Os conquistadores. Porto Alegre: L\&PM, 1986.

DEMANT, Peter. 0 mundo muçulmano. São Paulo: Contexto, 2008.

DUSSEL, Enrique. 1492: o encobrimento do outro: a origem do mito da modernidade: conferências de Frankfurt. Tradução Jaime A. Clasen. Petrópolis: RJ, Vozes, 1993.

Meditações anticartesianas sobre a origem do antidiscurso filosófico da modernidade. In SANTOS, Boaventura de S.; MENEZES, Maria P. (orgs.).

Epistemologias do Sul. SP: Cortez, 2010. 


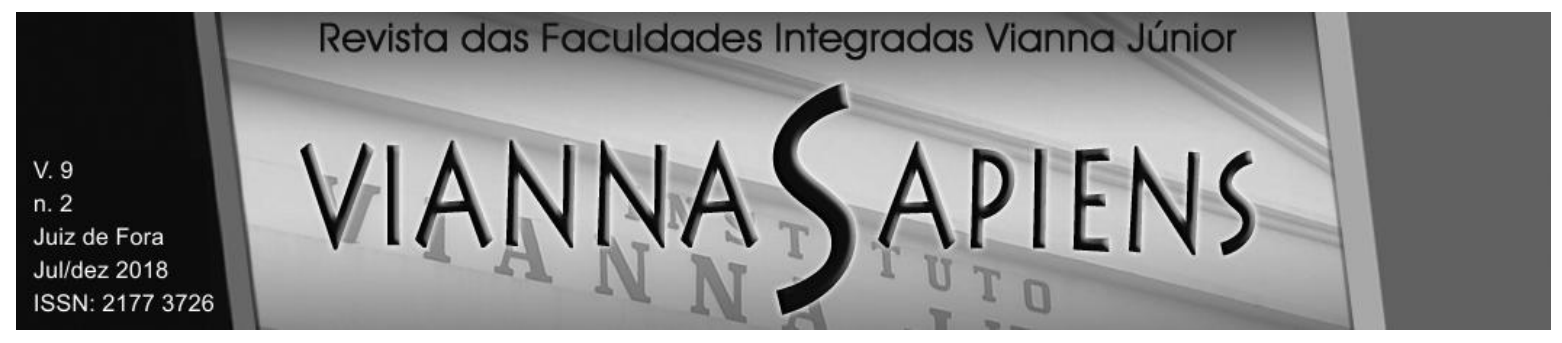

FERRAZ JR, Tércio Sampaio. Introdução ao estudo do direito: técnica, decisão, dominação. São Paulo: Atlas, 2003.

FRANCISCO, Rachel Herdy de Barros. Diálogo intercultural dos direitos humanos. Monografia vencedora do I concurso de monografia em direitos humanos do núcleo de direitos humanos do departamento de direito da pontifícia universidade católica do rio de janeiro. 2003. Disponível em:<http://www.dhnet.org.br/pdf>. Acesso em: 01 jun. 2013.

GALEANO, Eduardo. As veias abertas da América Latina. Tradução de Galeno de Freitas. 23. ed. Coleção estudos latino-americanos. Rio de Janeiro: Paz e terra, 1986.

GARAUDY, Roger. 0 ocidente é um acidente: por um diálogo das civilizações. Tradução de Virgínia da Mata-Machado. Rio de Janeiro: Salamandra, 1978.

GROSFOGUEL, Ramón. Para descolonizar os estudos de economia política e os estudos pós-coloniais: transmodernidade, pensamento de fronteira e colonialidade global. In SANTOS, Boaventura de Sousa; MENEZES, Maria Paula (orgs.).

Epistemologias do Sul. SP: Cortez, 2010.

HOBSBAWM, Eric. Era dos extremos: o breve século XX, 1914-1991. Trad. Marcos Santarrita. 2. ed. São Paulo: Companhia das Letras, 1997.

IBGE. PIB brasileiro em 2016. Disponível

em:<https://brasilemsintese.ibge.gov.br/contas-nacionais/pib-valores-

correntes.html . Acesso em 27 fev. 2017.

KI-ZERBO, Joseph (edit.). História geral da África, v.I: Metodologia e préhistória da África. 2.ed. Brasília: UNESCO, 2010.

MAGALHÃES, José Luiz Quadros de; REIS, Carolina dos. A utilização dos direitos humanos como dominação. Revista interdisciplinar de direito da Faculdade de Direito de Valença. Anual, ano 1, n.1. Juiz de Fora: Associada, 2010. 


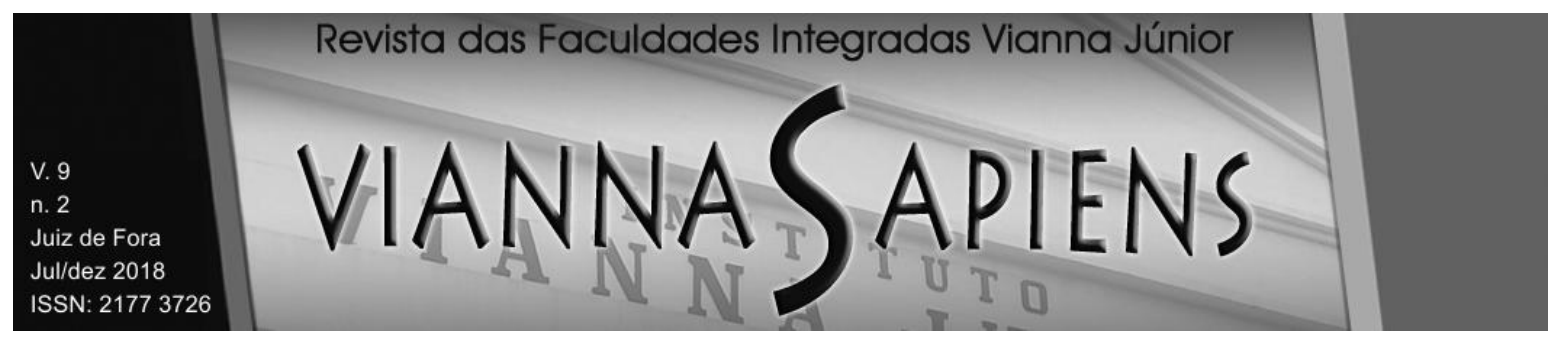

O estado plurinacional e o direito internacional moderno. Coleção para entender. Coord. BRANT, Leonardo N. C. Curitiba: Juruá, 2012.

MARTINS-COSTA, Judith. Pessoa, personalidade, dignidade: (ensaio de uma qualificação). São Paulo: Congregação da Faculdade de Direito da Universidade de São Paulo, 2003.

Orlando Villas Boas denuncia ocupação da amazônia. Disponível em: <https://www.youtube.com/watch?v=Gqln-OVNqxk>. Acesso em: 25 fev. 2017.

PACHUKANIS. A teoria geral do direito e o marxismo. Trad. Soveral Martins. Coimbra: Centelha, 1977.

PIMENTA, Rafael Sales. Diálogo da diferença. Dissertação de mestrado 2013. Disponível em: <http://www.unipac.br/site/bb/teses/teses6804ce35aa08c67eb7c12fc6411a4d6c.pdf $>$. Acesso em: 01 mar. 2017.

PIOVESAN, Flávia. Direitos humanos e o direito constitucional internacional. 13.ed. São Paulo: Saraiva, 2012.

SANTOS, Boaventura de Sousa. Para uma concepção multicultural dos direitos humanos. Rio de Janeiro: Contexto Internacional. v. 23, n. 1, janeiro/junho 2001.

. Para além do Pensamento Abissal: Das linhas globais a uma ecologia de saberes. Revista Crítica de Ciências Sociais. Outubro 2007.

. Um ocidente não ocidentalista? A filosofia à venda, a douta ignorância e a aposta de Pascal. In: SANTOS, Boaventura de S; MENEZES, Maria P. (orgs.).

Epistemologias do Sul. SP: Cortez, 2010.

SCHABAS, William. Genocídio. InO tribunal penal internacional: comentários ao estatuto de Roma. Orgs. STEINER, Sylvia H., CALDEIRA BRANT, Leonardo N. Belo Horizonte: Del Rey, 2016. 


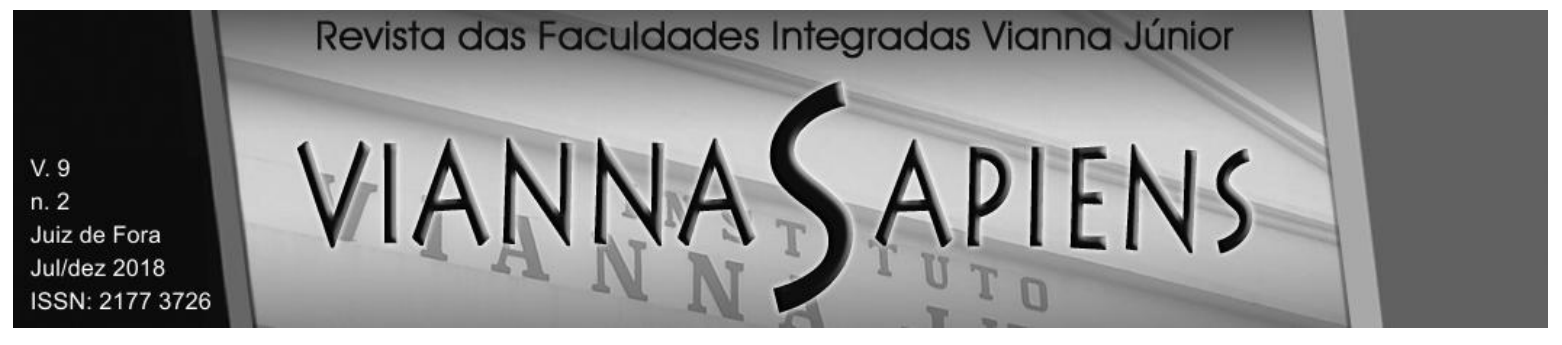

STANCIOLI, Brunello. Renúncia ao exercício de direitos da personalidade: ou como alguém se torna o que quiser. Belo Horizonte: Del Rey, 2010.

Recebido em 09/10/2018

Publicado em 21/12/2018 